\title{
MEANING ON TRANSLATION OF INDONESIAN-ENGLISH ADS TEXT
}

\author{
Purwani Indri Astuti \\ Department of English Education, University of Veteran Bangun Nusantara, Indonesia \\ Email: indripuspo@gmail.com
}

APA Citation: Astuti, P. I. (2017). Meaning on translation of Indonesian-English ads text. Indonesian EFL Journal, 3(1), 93-100

\begin{abstract}
This research was actually about the meaning of translation in Indonesian-English ads text, the booklet of PUD in Sukoharjo regency. Translating ads text is not simple because ads text has certain structure to be fulfilled. Then, to translate some cultural terms in ads text, it needs some considerations to keep the quality of the translation itself. One of the consideration s is about the concept of readibility that consists of length of sentence average, new words, and grammatical complexity. The research belonged to qualitative research and the data were all the phrases and the sentences in the booklet of PUD Sukoharjo regency. The methods of data collecting were questionaire, in-depth interview, and content analysis with the instrumens of questions, interview guides, and data card. The data were then analyzed by using Miles and Huberman interactive model while the data validity was data triangulation. The result of the research showed that the readibility of Indonesian-English ads text was rather low for the score of the readibilty rating instrument was 2.2 from the total score of 3 .
\end{abstract}

Keywords: translation, ads text, readibility

\section{INTRODUCTION}

In a world of business, it is needed a marketing strategy to promote the products. One of the strategies usually used by the producers is advertisement (ads). By using ads, producers can introduce some new products to consumers. It can also remind the consumers that the products are still better than others. Even that ads can keep the brands in ones' mind by showing the superiorities of the products (Wiratno in Sumarlam, 2005, p, 180). In some mass media, ads is effectively considered to be able to attract ones' attention because ads could be the attention-getting device. That is why, ads must represent the image of the product.

A good ads is an ads that all messages can be transfered well to consumers. It has some important elements to support it, such as pictures and colors, languages, lay out (for printed media) and harmonization among the actors, story board and languages (for electronic media). For some products that will be promoted in foreign countries, languages become the key aspect that determine the success of ads. In this case, ads could become a good mediator for the ones having different languages and different cultures.

Sukoharjo is one of regencies in Central Java that has some superior local products to promote, such as traditional music instruments, traditional furniture, shuttlecocks, clothes, traditional foods and beverages, etc. Such these products are very famous around Sukoharjo and become the speciality there. Even some of them are potentially to export, and few of them have been exported to some abroad. The producers (and most of them), are traditional ones that usually do not care about their markets or how to promote their products. They just produce and usually there are some brokers who can sell the products. In a short, the producers still use traditional marketing.

Sukoharjo government that catches this opportunity to increase the local economic growth, tried to support in marketing sector. The government, through its certain institution helped the producers to promote their products to some other foreign countries by making some ads (printed and electronic media). Jefkins (1994, $\mathrm{p}, 45-46$ ) said that commercial ads which was 
advertised by local government could be classified into commerce ads, and was famous for informative-commercial ads. In this ads, Sukoharjo government promoted the superior products to international consumers.

This research only focused on printed media, especially booklet to promote some superior local products outside the country that released by Sukoharjo regency. The booklet used bilingual texts, they were Indonesian and English. So, it is needed translation area to transfer the messages from producers to consumers.

Translating an ads is not easy because ads actually has its own style of language. The structure of the language is also different to the common ones. It has the specific characteristics. They are short, fluent, simple, neutral, straight to the point and interesting. Language plays an important role in making good ads. It can be started from the title, the selection of words for the title (something that is promising some benefits or words resulting miracles for the consumers) (Ogilvy, translated by Pertiwi, p. 75). More than that, if the ads involved the culture, the translator should think twice before he translates it. Some cases, there are some words don't have equal meanings in Taret Language (TL)

because of the cultural terms, but the translator should be smart in deciding the the translation. The translation of ads should be effective, having aesthetic sense, and must be easy to understand for the readers. If the translator can't translate the uniqueness of the cultural terms, it will effect the sustainability of the products. In other word, the quality of translation must be paid attention to.

There are some aspects to determine the quality of translation. Barnwell (1983) as citated by Suryawinata (2003) said that the quality of translation depends on accuracy, clarity and naturalness. Accuracy is about the understanding message of SL and transferring the meaning of the message correctly to TL. The main point of this aspect is about the loyalty of meaning in target language. Loyalty in translation doesn't refer to the form, but it refers to the meaning of SL to TL.
Next is clarity. Clarity shows the easiness level of a text to understand the meaning. The involvement of readers to determine the level of clarity and readibility becomes the important thing in language factors. Clarity has close relation to readibility. In other word, clarity means readibility. Readibility here is, of course, involving both SL and TL. It tends to discuss about the concept of words from SL to TL. A good translator ability for the concept of words can help him in doing translation. Theoritically, there are some factors determined the level of readibility. They are: 1) length of sentence average, 2) numbers of new words, 3) grammatical complexity of the language (Richards et.al (1985) in Nababan, 2003, p. 63). By this definition, it can also be said that clarity is affected by the translator's strategy. The translator's decision in choosing the meaning of a word or the decision in using foreignization or naturalization can make the translation becomes clearer or not.

The last is naturalness. Naturalness is about the effectiveness of translation. Naturalness means that the translation is interesting to read and enjoyable for the readers. In other word, the result of translation is very smooth so the reader doesn't realize that the text is a result of translation. Talking about effectiveness, Nababan (2003, p, 87) said that the effectiveness of translation is determined by 3 dimensions. They are : linguistics and cultural knowledge, purpose, intuition.

A translator must have linguistics knowledge because in doing his job, he must be able to transfer meaning from SL to TL. Besides that, he must also know the cultural knowledge of SL and TL. So, to get good meaning, a translator must understand the difference structure of SL and TL and also understand the culture context of SL and TL. As the main actor in translation process, a translator must make some decisions about his purpose that he would like to get. His decisions is very important to determine whether the result of translation is still loyal to SL, the style of language is suitable to SL, the level of readibility suits to the ability of readers and the use of 
translation strategy without making the ambiguity of meaning.

In the process of translation, it involves translator's intuition (Nababan, 2003, p. 92). Intuition has a function to determine the beauty of translation works, although one's can be different to others.

Based on the phenomenon and the theories mentioned above, the researcher determined the problem statement of the research was follow: How is the Meaning on Translation of Indonesian-English Ads Text based on Readibility Concept in Translation?

\section{METHOD}

This research belonged to descriptive qualitative research. It meaned the researcher tried to describe and identify in detail about the translation of Indonesian English ads text in details. In this case, the researcher found out the equal meaning of Indonesian-English ads text. The equal meaning here was seen from the understanding of the readers and measured by using readibility rating instrument level. Some numbers that appeared in this research symbolized the meaning of readibility level and were not operated into statistics formulas.

The data of the research were all phrases and sentences in Indonesian-English ads text of booklet, released by Sukoharjo regency, in the year of 2012. The number of total data were 92 data. After reducing data, the researcher still got 69 data ( 23 phrases and 46 sentences).

The method of collecting data were questionnaire, in-depth interview and content analysis. While the instruments of the research were question list, interview guide and data card.Questionaire was given to some informants to know the equal meaning of some Indonesian-English phrases and sentences that became the data. In-depth interview was held to some foreign informants to know their comments related to the meaning of translations for some phrases and sentences that potentially having the problem for meaning. Next, content analysis is technique of data collecting used by document notes. In this research, content analysis was used to collect the data (phrases and sentences) found on ads text of the booklet. Then all collected data were given the code number based on the classification. Example of Data Code was like this:

$$
\text { 1/Wcn.TC/Fr/1b }
$$

means

$1=$ Number of Data

Wen = Wacana

TC $=$ Tujuan \& Cara Pemaparan

$\mathrm{Fr} \quad=$ Frasa

$1 \mathrm{~b}=$ halaman 1 butir $\mathrm{b}$

The data sources were the Indonesian-English ads texts of booklet released by Sukoharjo regency and the informants. The informants were taken by purposive sampling with the criteria of Indonesian experts (Indonesian lecturers) and some foreign readers to know whether the English ads text could be understood or not.

The validity of the research was data triangulation. Here, the researcher got the data from some informants and foreign readers by using questionnaire and interview methods.

For the data analysis, the researcher used interactive models of Miles and Huberman. This model consists of 3 stages, they are reduction, display data and verifying or conclusion (Sutopo, 2002, p. 93). 


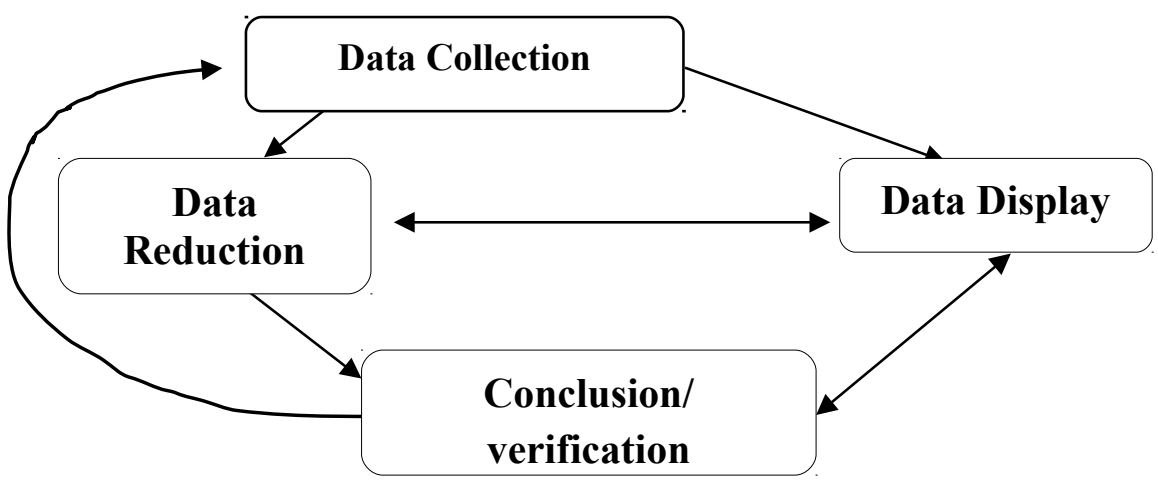

The steps of this model were 1) data collecting, 2) data reduction, 3) data display and 4) conclusion. In this research, the researcher got enough data, so it was not necessary for the researcher to get back to data collection again before conclude the result, finally.

\section{RESULTS AND DISCUSSION}

In analyzing the data, the researcher got 92 data but then the researcher reduced 23 of same data. So, the total data were 69 data that classified into 23 phrases and 46 sentences. The researcher revealed about meaning on translation of Indonesian-English Ads Text based on Readibility Concept.

In the concept of readibility, it refers to clarity that consists of 3 elements. They are a) length of sentence average, b) numbers of new words, and c) grammatical complexity of the language. The first point (Length of Sentence Average) refers to the average numbers of sentences in a text. The second poin (New Words) can possibly happen in TL because of the different culture between SL and TL. While the third point (Grammatical Complexity) refers to complex sentences used by translator.

Based on the result of data analysis, the researcher got some variations of the length of sentence average. To know about the length of sentence average, the reseacher gave the questionairre to some informants. The result could be visualized in the table as follow:

Table 1. Length of Sentence Average

\begin{tabular}{|c|c|c|c|c|}
\hline No & Length of Sentence Average & No of Data & Frequence & Criteria \\
\hline 1 & $\begin{array}{l}21 \text { words - more than } 29 \text { words per } \\
\text { sentence }\end{array}$ & $\begin{array}{l}\text { 24/Wcn.TC/Kal/2 } \\
\text { 25/Wcn.TC/Kal/2 } \\
\text { 28/Wcn.TC/Kal/4 } \\
\text { 31/Wcn.TC/Kal/5 } \\
\text { 37/Wcn.TC/Kal/6 } \\
\text { 40/Wcn.TC/Kal/7 } \\
\text { 41/Wcn.TC/Kal/7 } \\
\text { 44/Wcn.TC/Kal/8 } \\
\text { 45/Wcn.TC/Kal/7 } \\
\text { 47/Wcn.TC/Kal/9 } \\
\text { 52.b/Wcn.TC/Kal/11 } \\
\text { 59/Wcn.TC/Kal/13 } \\
\text { 70/Wcn.TC/Kal/16 } \\
\text { 88/Wcn.TC/Kal/21 }\end{array}$ & 14 & Difficult \\
\hline 2 & 15 words - 20 words per sentence & $\begin{array}{l}\text { 29/Wcn.TC/Kal/4 } \\
\text { 35/Wcn.TC/Kal/6 } \\
\text { 51/Wcn.TC/Kal/10 } \\
\text { 51.b/Wcn.TC/Kal/10 } \\
\text { 55/Wcn.TC/Kal/12 } \\
\text { 57/Wcn.TC/Kal/12 }\end{array}$ & 14 & Fair \\
\hline
\end{tabular}




\begin{tabular}{|c|c|c|c|c|}
\hline & & $\begin{array}{l}\text { 63/Wcn.TC/Kal/14 } \\
\text { 67/Wcn.TC/Kal/15 } \\
\text { 73.b/Wcn.TC/Kal/17 } \\
\text { 77/Wcn.TC/Kal/18 } \\
\text { 79/Wcn.TC/Kal/19 } \\
\text { 84/Wcn.TC/Kal/20 } \\
\text { 85/Wcn.TC/Kal/20 } \\
\text { 87/Wcn.TC/Kal/21 }\end{array}$ & & \\
\hline \multirow[t]{2}{*}{3} & $\begin{array}{l}14 \text { words - below } 8 \text { words per } \\
\text { sentence }\end{array}$ & $\begin{array}{l}\text { 32/Wcn.TC/Kal/5 } \\
\text { 33/Wcn.TC/Kal/5 } \\
\text { 33.b/Wcn.TC/Kal/5 } \\
\text { 36/Wcn.TC/Kal/6 } \\
\text { 48/Wcn.TC/Kal/9 } \\
\text { 56/Wcn.TC/Kal/12 } \\
\text { 60/Wcn.TC/Kal/13 } \\
\text { 61/Wcn.TC/Kal/13 } \\
\text { 64/Wcn.TC/Kal/14 } \\
\text { 67/Wcn.TC/Kal/15 } \\
\text { 68/Wcn.TC/Kal/15 } \\
\text { 73/Wcn.TC/Kal/17 } \\
\text { 75/Wcn.TC/Kal/18 } \\
\text { 76/Wcn.TC/Kal/18 } \\
\text { 81/Wcn.TC/Kal/19 } \\
\text { 82/Wcn.TC/Kal/19 } \\
\text { 86/Wcn.TC/Kal/20 } \\
\text { 89/Wcn.TC/Kal/21 }\end{array}$ & 18 & Easy \\
\hline & Total Number & & 46 & 100,00 \\
\hline
\end{tabular}

From the table above, it could be seen that $39,13 \%$ of the sentence average length were categorized into 'easy'. It means that the length of a sentence was built by maximally
14 words. Most of them were simple sentences either active or passive sentences. The examples are taken randomly:

Table 2. Examples of Sentence Average Length Variation

\begin{tabular}{|c|c|c|c|}
\hline No & Coding & SL & $\mathrm{TL}$ \\
\hline 1 & 61/Wcn.TC/Kal/13 & $\begin{array}{l}\text { Jumlah produksi mencapai } \\
125.000 .000 \text { buah per tahunnya. }\end{array}$ & $\begin{array}{l}\text { The production can reach about } \\
125.000 .000 \text { items in a year. }\end{array}$ \\
\hline 2 & 76/Wcn.TC/Kal/18 & $\begin{array}{l}\text { Jumlah pengrajin terdapat } 534 \text { orang } \\
\text { dan menyerap tenaga kerja } 1.122 \\
\text { orang. }\end{array}$ & $\begin{array}{l}\text { There are } 534 \text { people, which absorb } \\
1.122 \text { workers. }\end{array}$ \\
\hline 3 & 86/Wcn.TC/Kal/20 & $\begin{array}{l}\text { Hasil produksinya telah dipasarkan ke } \\
\text { seluruh wilayah Indonesia. }\end{array}$ & $\begin{array}{l}\text { The production has been sold to every } \\
\text { region in Indonesia. }\end{array}$ \\
\hline 4 & 55/Wcn.TC/Kal/12 & $\begin{array}{l}\text { Industri gamelan ini ada di desa } \\
\text { Wirun dan desa Laban Kecamatan } \\
\text { Mojolaban }\end{array}$ & $\begin{array}{l}\text { The industry of gamelan tkes place at } \\
\text { Wirun village and Laban village the } \\
\text { Mojolaban sub district. }\end{array}$ \\
\hline 5 & 28/Wcn.TC/Kal/4 & $\begin{array}{l}\text { Kabupaten Sukoharjo terkenal } \\
\text { dengan sebutan kota tekstil, karena } \\
\text { lebih dari } 10 \text { perusahaan besar dan } \\
\text { menengah bergerak di bidang tekstil, } \\
\text { diantaranya: Sritex, Batik Keris, } \\
\text { Danliris, Tyfountex, Sukoharjotex, } \\
\text { Sandang Anggun Moratex, Panca } \\
\text { Bintang, Panrama Vista Garment, } \\
\text { Sumber Sandang Artogunan dan telah } \\
\text { menampung sekitar } 61.268 \text { orang } \\
\text { tenaga kerja dengan jumlah } \\
\text { produksinya mencapai } 545.270 .000 \\
\text { meter per tahun nya. }\end{array}$ & $\begin{array}{l}\text { The regency of Sukoharjo is well } \\
\text { known as a toen of textille, because } \\
\text { more than ten big and middle } \\
\text { companies active in textille industry, } \\
\text { for example Sritex, Batik Keris, } \\
\text { Danliris, Tyfountex, Sukoharjotex, } \\
\text { Sandang Anggun Moratex, Panca } \\
\text { Bintang, Panrama Vista Garment, } \\
\text { Sumber Sandang Artogunan and held } \\
61.268 \text { workers. }\end{array}$ \\
\hline
\end{tabular}

Length of sentence average isn't the one and only determination to see whether the sentence is readable or not. But there are other factors can also become causes of 
readibility, for examples new words and grammar complexity.

Data number 61,76 and 86 were categorized into easy level of readibility. Data number 61 belongs to simple sentence and can be easy to understand. This is because length of the sentence is short enough (only having 10 words in a sentence) and no new words there. Data number 76 is relatively easy to understand and shorter than previous sentence (having 8 words in a sentence), though it doesn't belong to simple for having 2 predicates. While data number 86 is a passive sentence and has more words ( 10 words in a sentence) but it is still easy to understand. For data number 55 , it belongs to fair level of readibility because there are much more words in a sentence (16 words) and there is a new word (gamelan) in TL. The last example, data number 28 is the longest sentence in the examples. It has more than 29 words in a sentence and categorized into difficult level of readibility. In fact, this sentence can be easy to understand for it is simple sentence and most of the words in that sentence are about name of companies.

The category above are not always true for the fact that long sentences can also be easy to understand. This is because the sentence only consists of 1 subject and 1 predicate, no new words in TL and most of the words in the sentence are only mentioning the name of companies or the name of area, etc.

The second point is about new words in TL. New words have relation to meaning, the most important thing in translation. Talking about meaning, it can't be separated by the culture covering the context of both languages (SL \& TL). So, it must be very careful for the translators to transfer meaning having different culture between SL and TL. In some cases, it is impossible for the translators to find out the equal meaning for some terms. In this case, the translator usually try to convey the concept of the word. Related to the culture itself, there are many things considered as culture, for examples: clothes, art, weapon, foods, tradition and so on.

Translating ads text is different to translating other texts because it has certain style of language. Translator must think about the essence of the ads, by transferring the meaning in simple way with limited space but must be understandable and interesting for audience (mass). For the booklet of PUD in Sukoharjo regency, the result of the research showed that the construction of SL ads text was effective enough to translate. It could be explained furthur in the table below: In the booklet of PUD in Sukoharjo regency, it was found 69 data. The new words rose in phrases and were repeated insome sentences. From 23 data of phrases, 18 data $(78,26 \%)$ were about cultural terms (cloth, foods, drink, music instrument and furniture). Based on the research result, 5 from 18 data $(27,78 \%)$ of cultural terms are still endured in the original terms (transliteration), 6 from 18 data (33,33\%) of cultural terms belong to naturalization and 7 data $(38,89 \%)$ can be translated as well. For the detail data, they can be seen in the table below:

Table 3. Data of New Words Related to Cultural Terms

\begin{tabular}{lllll}
\hline No & Number of Data & Terms & TL & Note \\
\hline 1 & 6/Wcn.TC/Fr/1.d & Industri Tekstil & Textille Industry & Ntrl \\
\hline 2 & 7/Wcn.TC/Fr/1.e & Mebel Kayu & The Wooden Furniture & Done \\
\hline 3 & $8 /$ Wcn.TC/Fr/1.f & Mebel Rotan & Rattan Furniture & Ntrl \\
\hline 4 & $9 /$ Wcn.TC/Fr/1.g & Industri Kaca Grafir dan Ukir Kaca & An Engraving \& Glass Carving & Done \\
\hline 5 & $10 / \mathrm{Wcn} . \mathrm{TC} / \mathrm{Fr} / 1 . \mathrm{h}$ & Kerajinan Tatah Sungging & Enameling Inlaid Craft & Done \\
\hline 6 & $11 / \mathrm{Wcn} . \mathrm{TC} / \mathrm{Fr} / 1 . \mathrm{i}$ & Kerajinan Gitar & Guitar Craft & Ntrl \\
\hline 7 & $12 / \mathrm{Wcn} . \mathrm{TC} / \mathrm{Fr} / 1 . \mathrm{j}$ & Kain Batik & Batik & Trnslt \\
\hline 8 & $13 / \mathrm{Wcn} . \mathrm{TC} / \mathrm{Fr} / 1 . \mathrm{k}$ & Alkohol & Alcohol & Ntrl \\
\hline 9 & $14 / \mathrm{Wcn} . \mathrm{TC} / \mathrm{Fr} / 1.1$ & Kerajinan Gamelan & Gamelan Craft & Trnslt \\
\hline 10 & $15 / \mathrm{Wcn} . \mathrm{TC} / \mathrm{Fr} / 1 . \mathrm{m}$ & Industri Genteng & A Tight Roof Industry & Done \\
\hline 11 & $16 / \mathrm{Wcn} . \mathrm{TC} / \mathrm{Fr} / 1 . \mathrm{n}$ & Kerajinan Shuttlecock & Shuttlecocks & Trnslt \\
\hline 12 & $17 / \mathrm{Wcn} . \mathrm{TC} / \mathrm{Fr} / 1.0$ & Kerajinan Tenun Sarung Goyor & Sarong Goyor Spindle Craft & Ntrl \\
\hline 13 & $18 / \mathrm{Wcn} . \mathrm{TC} / \mathrm{Fr} / 1 . \mathrm{p}$ & Hortikultura & Horticulture & Ntrl \\
\hline
\end{tabular}




\begin{tabular}{lllll}
\hline 14 & $19 / \mathrm{Wcn} . \mathrm{TC} / \mathrm{Fr} / 1 . \mathrm{q}$ & Industri Jamur Lingzhi & Lingzhi Mushroom Industry & Done \\
\hline 15 & $20 / \mathrm{Wcn} . \mathrm{TC} / \mathrm{Fr} / 1 . \mathrm{r}$ & Emping Mlinjo & Emping Mlinjo & Trnslt \\
\hline 16 & $21 / \mathrm{Wcn} . \mathrm{TC} / \mathrm{Fr} / 1 . \mathrm{s}$ & Industri Jenang Rasikan & Jenang Rasikan Industry & Trnslt \\
\hline 17 & $22 / \mathrm{Wcn} . \mathrm{TC} / \mathrm{Fr} / 1 . \mathrm{t}$ & Jamu & The Healing Herb & Done \\
\hline 18 & $23 / \mathrm{Wcn} . \mathrm{TC} / \mathrm{Fr} / 1 . \mathrm{u}$ & Keripik Belut & The Eel Chips & Done \\
\hline
\end{tabular}

From the data above, it could be explained that $26,08 \%$ of total data were about cultural terms. Some of them could be translated well because of the equal meaning, but some of them couldn't be translated for the different cultures between SL and TL. The ones didn't have equal meaning were about traditional music instrument (gamelan), clothes (batik) and traditional foods (emping mlinjo and jenang rasikan).

Based on the result of questionaire, the translation of jenang rasikan and emping mlinjo couldn't be understood well by the foreign readers. This was because jenang rasikan and emping mlinjo didn't have same concept in TL, and also were not so popular yet in abroad. This condition was different to a data of guitar craft which became the translation of kerajinan gitar. This translation could be understood well because guitar had same concept and equal meaning between SL to TL.

For the terms that couldn't be translated well for not having equal meaning were about batik cloth, foods, traditional music instrument. While the ones that could be translated as adopted terms were about drink (alcohol), music instrument (guitar), furniture (rattan).

The third point is about grammatical complexity. Usually, grammatical complexity happens in complex sentence. Complex sentence is more difficult to understand than simple sentence. This is because in complex sentence, it may consist of more than one idea. So, it must have more than one clause. From the analysis of grammatical complexity in the ads text of booklet PUD Kab. Sukoharjo, it could be performed below:

Table 4. Grammatical Complexity

\begin{tabular}{llll}
\hline No & Data Coding & SL & TL \\
\hline 1 & $37 /$ Wcn.TC/Kal/6 & $\begin{array}{l}\text { Produksi rotan ini, 90 \% telah } \\
\text { mampu menembus pasaran } \\
\text { internasional di berbagai negara }\end{array}$ & $\begin{array}{l}\text { The production can reach about 400.000 } \\
\text { bonus in a year and 90\% of it has broken } \\
\text { through to the international market in } \\
\text { several countries. }\end{array}$ \\
\hline 2 & $70 /$ Wcn.TC/Kal/16 & $\begin{array}{l}\text { Potensi produksi tanaman } \\
\text { hortikultura di Kabupaten Sukoharjo } \\
\text { adalah melon, dengan luas lahan 173 } \\
\text { ha. }\end{array}$ & $\begin{array}{l}\text { The potential production of the } \\
\text { Horticulture plants at Sukoharjo regency } \\
\text { consist of Melon with the land wide of } \\
173 \text { hectares can produce 5.690 tons, } \\
\end{array}$ \\
& & $\begin{array}{l}\text { mango the total number of 78.198 } \\
\text { mango's trees can produce 12.138 tons, } \\
\text { kedondong with 12.823 trees can } \\
\text { produce 1.023 tons, mlinjo is produced } \\
\text { around 787 tons and banana which is } \\
\text { produced around 3.619 tons. }\end{array}$ \\
& &
\end{tabular}

From the table above, we can see that complex sentence usually uses complex grammar because there are dependent clauses that has function as modifiers. This situation can make the text becomes difficult to understand. More than that, if there are many new words that don't have the equal meaning or same concept in TL, the readibility becomes lower and lower. The more the complex sentences in a text is, the lower the readibility of a text is.

For example, data number 70 is a simple sentence in SL, but it changed into complex sentence in TL. The length sentence average in TL is long ( 59 words). Besides that, there were some new words that didn't have any equal meaning in TL. So, it is difficult for the foreign reader to understand the meaning of the text. On the other hand, 
data number 69 belongs to grammatical compexity for the complex sentence. It also came to category of fair in length sentence average ( 23 words), but it was still rather easy to understand for the foreign readers because it didn't have any new or difficult words. So, complexity grammar had to get much pay attention for the translator because it became the translator's determination in transferring the message.

\section{CONCLUSION}

Meaning is the most important thing in translation works. In this research, meaning was shown by the concept of readibility that had 3 items in it. They were length of sentence average, new words, and grammatical complexity.

From the analysis of those three items, it can be concluded that the length of sentence average in the booklet of PUD Sukoharjo regency was in the criteria of easy $(39,13 \%)$. This criteria showed that each sentence was built not more than 14 words. Then about the new words, the booklet of PUD Sukoharjo regency was completed by some cultural terms that didn't have the same concept in TL. This situation could make difficult for the foreign readers to understand the meaning. Last, grammatical complexity in the booklet of PUD Sukoharjo regency was not found much. Only 4,34\% belonged to grammatical complexity.

Besides, from the result of questionairre that were distributed to the informants, it showed that the average score for readibility of text was 2,22 (for the maximal score 3 ). It means that the result of translation couldn't be fully understood.

\section{REFERENCES}

Jefkin, F. (1994). Periklanan. Jakarta: Penerbit Erlangga. Ogilvy, D. (n.d). Pengakuan orang iklan. Jakarta: Pustaka Tangga

Nababan, M. R. (2003). Teori menerjemah bahasa Inggris. Yogyakarta: Pustaka Pelajar

Sumarlam. (2005). Teori dan praktik analisis wacana. Surakarta: Pustaka Cakra.

Sutopo, H. B. (2002). Metodologi penelitian kualitatif: Dasar dan terapannya dalam penelitian. Surakarta: Sebelas Maret University Press.

Suryawinata, Z., \& Haryanto, S. (2003). Translation (Bahasan teori dan penuntun praktis menerjemahkan). Yogyakarta: Penerbit Kanisius 